\title{
Genotyping of potato samples from the GenAgro ICG SB RAS collection using DNA markers of genes conferring resistance to phytopathogens
}

\author{
I.V. Totsky ${ }^{1,2}$ @, I.V. Rozanova ${ }^{1,3}$, A.D. Safonova ${ }^{2}$, A.S. Batov ${ }^{2}$, Yu.A. Gureeva ${ }^{2}$, E.K. Khlestkina ${ }^{1,3}$, A.V. Kochetov ${ }^{1}$ \\ ${ }^{1}$ Institute of Cytology and Genetics of the Siberian Branch of the Russian Academy of Sciences, Novosibirsk, Russia \\ ${ }^{2}$ Siberian Research Institute of Plant Production and Breeding - Branch of the Institute of Cytology and Genetics \\ of the Siberian Branch of the Russian Academy of Sciences, Novosibirsk, Russia \\ ${ }^{3}$ Federal Research Center the N.I. Vavilov All-Russian Institute of Plant Genetic Resources (VIR), St. Petersburg, Russia \\ 凶totsky@bionet.nsc.ru
}

Abstract. Wart (a disease caused by Synchytrium endobioticum) and golden cyst potato nematode (Globodera rostochiensis), which parasitize the roots of the host plant, cause significant damage to potato crop. Both of these disease factors are quarantined in the Russian Federation, and each registered variety is tested for resistance to their most common races and pathotypes. The main method of opposing such diseases is by the development of resistant varieties. An important step in this process is the selection of resistant genotypes from the population and the estimation of the resistance of hybrids obtained by crosses during the breeding process. Conducting a permanent phenotypic evaluation is associated with difficulties, for example, it is not always possible to work with pathogens, and phenotypic evaluation is very costly and time consuming. However, the use of DNA markers linked to resistance genes can significantly speed up and reduce the cost of the breeding process. The aim of the study was to screen the GenAgro potato collection of ICG SB RAS using known diagnostic PCR markers linked to golden potato cyst nematode and wart resistance. Genotyping was carried out on 73 potato samples using three DNA markers 57R, CP113, Gro1-4 associated with nematode resistance and one marker, NL25, associated with wart resistance. The genotyping data were compared with the data on the resistance of the collection samples. Only the 57R marker had a high level of correlation (Spearman $\mathrm{R}=0.722008, p=0.000000, p<0.05$ ) between resistance and the presence of a diagnostic fragment. The diagnostic efficiency of the 57R marker was $86.11 \%$. This marker can be successfully used for screening a collection, searching for resistant genotypes and marker-assisted selection. The other markers showed a low correlation between the presence of the DNA marker and resistance. The diagnostic efficiency of the CP113 marker was only $44.44 \%$. Spearman's correlation coefficient (Spearman $\mathrm{R}=-0.109218, p=0.361104, p<0.05$ ) did not show significant correlation between resistance and the DNA marker. The diagnostic efficiency of the NL25 marker was $61.11 \%$. No significant correlation was found between the NL25 marker and resistance (Spearman $\mathrm{R}=-0.017946, p=0.881061, p<0.05$ ). The use of these markers for the search for resistant samples is not advisable.

Key words: golden potato cyst nematode; wart; potato; DNA markers 57R; NL25; CP113; Gro1-4.

For citation: Totsky I.V., Rozanova I.V., Safonova A.D., Batov A.S., Gureeva Yu.A., Khlestkina E.K., Kochetov A.V. Genotyping of potato samples from the GenAgro ICG SB RAS collection using DNA markers of genes conferring resistance to phytopathogens. Vavilovskii Zhurnal Genetiki i Selektsii = Vavilov Journal of Genetics and Breeding. 2021;25(6):677-686. DOI 10.18699/VJ21.077

\section{Генотипирование образцов картофеля коллекции «ГенАгро» ИЦиГ СО РАН с применением ДНК-маркеров генов устойчивости к фитопатогенам}

\author{
И.В. Тоцкий ${ }^{1,2}$ 困, И.В. Розанова ${ }^{1,3}$, А.А. Сафонова 2 , А.С. Батов², Ю.А. Гуреева ${ }^{2}$, Е.К. Хлесткина ${ }^{1,3}$, А.В. Кочетов ${ }^{1}$

\footnotetext{
1 Федеральный исследовательский центр Институт цитологии и генетики Сибирского отделения Российской академии наук, Новосибирск, Россия

${ }^{2}$ Сибирский научно-исследовательский институт растениеводства и селекции - филиал Института цитологии и генетики Сибирского отделения Российской академии наук, пос. Краснообск, Новосибирская область, Россия

${ }^{3}$ Федеральный исследовательский центр Всероссийский институт генетических ресурсов растений им. Н.И. Вавилова (ВИР), Санкт-Петербург, Россия ه totsky@bionet.nsc.ru
}

\begin{abstract}
Аннотация. Значительный ущерб урожаю картофеля наносят рак картофеля (болезнь, вызываемая патогенным грибом Synchytrium endobioticum) и золотистая картофельная нематода (Globodera rostochiensis), паразитирующая на корнях растения-хозяина. Оба этих фактора являются объектами внешнего и внутреннего карантина в Российской Федерации, и каждый сорт, регистрируемый в РФ, проходит проверку на устойчивость к наиболее распространенным их расам и патотипам. Основной метод борьбы с подобными заболеваниями - выведение
\end{abstract}




\begin{abstract}
устойчивых сортов. Важным этапом в этом процессе является отбор устойчивых генотипов из популяции и оценка устойчивости гибридов, полученных при скрещиваниях во время селекционного процесса. Проведение постоянной фенотипической оценки связано с рядом трудностей, а именно: не всегда есть возможность работать с патогенами, сама фенотипическая оценка очень затратная и трудоемкая. Однако применение ДНК-маркеров, сцепленных с генами устойчивости, может значительно ускорить и удешевить процесс. Целью исследования было проведение скрининга коллекции картофеля «ГенАгро» (ИЦиГ СО РАН) с использованием ПЦР-маркеров, разработанных для диагностики устойчивости к золотистой картофельной нематоде и раку картофеля. Семьдесят три образца из коллекции «ГенАгро» ИЦиГ СО РАН были генотипированы ДНК-маркерами 57R, CP113, Gro 1-4, сцепленными с устойчивостью к нематоде, и маркером NL25 для устойчивости к раку. Результаты генотипирования сопоставлены с уровнем восприимчивости образцов к болезням. Высокий уровень корреляции (коэффициент корреляции Спирмена Spearman $\mathrm{R}=0.722008, p=0.000000, p<0.05$ ) между устойчивостью и наличием диагностического фрагмента был показан только для маркера 57R. Диагностическая эффективность маркера 57R составила 86.11 \%. Данный маркер можно успешно использовать для поиска устойчивых генотипов и проведения маркер-ориентированной селекции. Для остальных маркеров достоверных корреляций не выявлено. Диагностическая эффективность применения маркера СР113 равнялась всего 44.44 \%, а коэффициент корреляции Спирмена (Spearman $\mathrm{R}=-0.109218, p=0.361104, p<0.05$ ) показывал отсутствие значимой корреляция между устойчивостью и ДНК-маркером. Диагностическая эффективность маркера NL25 составила 61.11 \%. 3начимой корреляции между маркером NL25 и устойчивостью не обнаружено (Spearman $\mathrm{R}=-0.017946, p=0.881061$, $p<0.05)$. Использование этих маркеров для поиска устойчивых образцов нецелесообразно.

Ключевые слова: золотистая картофельная нематода; рак картофеля; картофель; ДНК-маркеры 57R; NL25; CP113; Gro1-4.
\end{abstract}

\section{Introduction}

Potato is one of the most important crops in the world and is the world's fifth largest staple food crop by volume (FAO Statistical Pocketbook, 2019). One of the possible reasons for a decrease in yield is the damage of potatoes by various factors. Especially dangerous for potatoes are golden potato cyst nematode (Globodera rostochiensis) and potato wart (pathogen-Synchytrium endobioticum). They are quarantined in the Russian Federation. Data on resistance to G. rostochiensis and S. endobioticum are required when registering a potato variety in the State Register of Selection Achievements Authorized for Use (State Register... 2019; https://gossortrf.ru/).

Potato cyst nematode (PCN) can cause significant damage to the potato yield, which can reach $80-90 \%$ (Khiutti et al., 2017; Klimenko et al., 2017). Today, 5 pathotypes of this pest are known in the world: Ro1, Ro2, Ro3, Ro4, Ro5 (Kort et al., 1977; Khiutti et al., 2017), while in Russia only the Ro1 pathotype of PCN has been detected at the moment (Limantseva et al., 2014).

Potato wart affects from 35 (Koretsky, 1970) to $100 \%$ (Hampson, 1993) of the yield. There are 43 wart pathogens in Europe today (Baayen et al., 2006). Only a few varieties affected by this disease are registered in the State Register of Selection Achievements (State Register... 2019; https:// gossortrf.ru/).

One of the main methods of dealing with these pests is the development of resistant potato varieties. Accordingly, it is important to detect genes responsible for resistance to PCN, study their heritability, develop DNA markers linked to these genes, and use genes in breeding in marker-assisted selection schemes.

The potato has 7 loci of resistance to PCN on chromosomes III (Gro1.4-QTL (Kreike et al., 1996)), V (Grpl-QTL (Rouppe van der Voort et al., 1998), Hl (Gebhardt et al., 1993), GroVl (Pineda et al., 1993)), VII (Grol (Barone et al., 1990; Leister et al., 1996)), X (Gro1.2-QTL (Kreike et al., 1993)), XI (Gro1.3-QTL (Kreike et al., 1993)). Four loci (Gro1.4, Grp1, Gro1.2, and Gro1.3) provide partial resistance, while three others (H1, GroVl, and Grol) give high resistance to one or more pathotypes (Gebhardt, Valkonen, 2001; Bakker et al., 2004; Ramakrishnan et al., 2015). DNA markers have made it possible to identify complex loci containing several $R$-genes, including a locus containing two genes ( $\mathrm{Hl}, \mathrm{GroVl})$ for PCN resistance, which was identified on chromosome $\mathrm{V}$ in two different potato species (Gebhardt, Valkonen, 2001).

The $H 1$ resistance gene is introgressed into breeding varieties from Solanum tuberosum ssp. andigenum and $S$. vernei (Toxopeus, Huijsman, 1953). This gene is dominant and determines resistance to pathotypes Ro1 and Ro4 of G. rostochiensis (Jones et al., 1981; Gebhardt, Valkonen, 2001; Bakker et al., 2004); according to other data, it determines resistance to pathotypes Ro5 and Ro6 (Pajerowska-Mukhtar et al., 2009; Milczarek et al., 2011; Lopez-Pardo et al., 2013; Ramakrishnan et al., 2015). This gene is located at the distal part of the long arm of the V chromosome (Gebhardt et al., 1993; Pineda et al., 1993) and encodes the CC-NBS-LRR protein (coiled coil/nucleotide-binding/leucine-rich repeat). The $H 1$ gene is the only nematode resistance gene for which Flora's geneto-gene interaction concept has been validated by classical genetic analysis (Flor, 1971; Janssen et al., 1991; Gebhardt, Valkonen, 2001). The $H 1$ resistance gene corresponded to the Avr gene of golden potato cyst nematode G. rostochiensis.

The GroV1 gene originates from the wild potato species S. vernei, is linked to the H1 locus (Jacobs et al., 1996), and is responsible for resistance to the Rol pathotype of G. rostochiensis (Jacobs et al., 1996; Milczarek et al., 2011; Ramakrishnan et al., 2015).

The Grol locus is localized on chromosome VII and contains a family of genes Grol-1, Gro1-2, Grol-3, Gro1-4, Gro1-5, Gro1-6, Gro1-8, Gro1-10, Gro1-11, Gro1-12 and Gro1-14, as well as a number of pseudogenes (Barone et al., 1990; Leister et al., 1996; Paal et al., 2004). J. Paal and colleagues showed that the Grol-4 gene is a monogenic dominant gene responsible for resistance to the Rol pathotype of $G$. rostochiensis and encodes a protein belonging to the TIR-NB-LRR class of proteins. Grol-4 was introduced into 
S. tuberosum from the wild potato $S$. spegazzinii (Ballvora et al., 1995; Gebhardt, Valkonen, 2001; Gebhardt et al., 2004; Paal et al., 2004; Kuhl, 2011; Milczarek et al., 2011; Ramakrishnan et al., 2015).

A number of loci of quantitative traits associated with resistance to cyst nematodes were mapped in the potato genome: Gro1.2, Gro1.3, and Grol.4 determining resistance to G. rostochiensis were localized on chromosomes X, XI, and III. In this case, S. spegazzinii was the source of resistance (Kreike et al., 1993, 1996).

The Grp1 locus provides a broad spectrum of resistance to both cyst nematodes $G$. rostochiensis and $G$. pallida. It has been mapped to chromosome V (Rouppe van der Voort et al., 1998, 2000) and determines resistance to the Ro5 pathotype of G. rostochiensis (Finkers-Tomczak et al., 2009; Milczarek et al., 2011; Ramakrishnan et al., 2015).

A significant number of diagnostic DNA markers have been developed for the $H 1$ gene. Among them are markers CD78 (Pineda et al., 1993), TG689 (Milczarek et al., 2011; LopezPardo et al., 2013), N146, N195 (Mori et al., 2011; Asano et al., 2012), CP113 (Gebhardt et al., 1993; Niewöhner et al., 1995; Skupinová et al., 2002; Milczarek et al., 2011), TG689/ TG689indel12 (Galek et al., 2011), 239E4left (Bakker et al., 2004; Pajerowska-Mukhtar et al., 2009; Milczarek et al., 2011), EM15 (repulsion) and CMI (coupling) (Bakker et al., 2004), 57R (Finkers-Tomczak et al., 2011; Schultz et al., 2012; Milczarek et al., 2014). Markers have also been designed for other genes and QTLs. For example, markers TG69 (Pineda et al., 1993), SCAR-U14, and SCAR-X02 have been developed for the GroVI gene (Jacobs et al., 1996; Milczarek et al., 2011); markers CP56 and St3.3.2 (Barone et al., 1990; Leister et al., 1996), CP56, CP51(c), GP516(c) were selected for the Grol locus (Ballvora et al., 1995; Kuhl, 2011). Markers Gro1-4 (Gebhardt et al., 2004; Paal et al., 2004; Milczarek et al., 2011) and Gro1-4-1 (Asano et al., 2012) were designed for the Gro1-4 gene. For Grp1-QTL, markers GP21 and GP179 (Rouppe van der Voort et al., 1998), TG432 (Finkers-Tomczak et al., 2009; Milczarek et al., 2011) have been developed. The TG63 marker was selected for Gro1.2-QTL (Kreike et al., 1993). Markers Ssp75 and TG30 have been developed for Gro1.3-QTL (Kreike et al., 1993). The Ssp8 marker was designed for Gro1.4-QTL (Kreike et al., 1996).

A number of genes for resistance to wart ( $S$. endobioticum) have been found in potatoes. These are the following genes: Sen 1, located on the XI chromosome (Hehl et al., 1999); Sen 1-4 mapped to chromosome IV (Brugmans et al., 2006); locus Sen18-IX, located on chromosome IX; locus Sen2/6/18-I, located on chromosome I (Ballvora et al., 2011); locus Xla-TNL found on chromosome XI (Bartkiewicz et al., 2018); the Sen2 locus mapped to chromosome XI (Plich et al., 2018); the Sen 3 locus was mapped on chromosome XI in the same region as the Sen 1 gene (Prodhomme et al., 2019); the authors suggested that Sen 3 could be either a Sen 1 paralogue from the same cluster or an allelic variant of the Sen 1 gene.

QTLs responsible for resistance to races 1, 2, 6 and 18 of wart are found on other chromosomes: chromosome I (to race 2), chromosome II (to races 6, 18), chromosome VI (to races $1,2,6,18$ ), chromosome VII (to races $2,6,18$ ), chromo- some VIII (to races 1, 2, 6, 18), chromosome $\mathrm{X}$ (to races 2, 6, 18), chromosome XI (to races 2, 6, 18) (Groth et al., 2013). J.E. Obidiegwu and colleagues also found additional wart resistance loci on chromosomes I, IV, X, XI, and XII that were less influential than the main genes (Obidiegwu et al., 2015). Minor QTLs located on the chromosome X further affect resistance to race 18 of wart (Bartkiewicz et al., 2018).

The Sen 1 and Sen 1-4 genes determine the resistance to race 1 of the potato wart pathogen; in both cases, resistance is determined by the dominant alleles of the genes. The Sen 1 gene is located at the distal part of the long arm of chromosome XI (Hehl et al., 1999; Obidiegwu et al., 2014). However, it should be noted that J.E. Obidiegwu et al. (2015), using genome-wide association studies (GWAS), identified the Sen $1 / R S e$-XIa multi-allelic locus on potato chromosome XI as the main factor of resistance to four $S$. endobioticum races (races 1, 2, 6 and 18) (Obidiegwu et al., 2015). The Sen1-4 gene is located on the long arm of chromosome IV at a distance of $5 \mathrm{cM}$ from the centromere (Brugmans et al., 2006).

The Xla-TNL locus on potato chromosome XI is linked to resistance to races 18 and 6 and can be considered as one of the main factors of wart resistance (Bartkiewicz et al., 2018).

The Sen 2 locus is mapped to chromosome XI and is a dominant monogenic locus that provides a high level of resistance to eight races of $S$. endobioticum simultaneously: 1 (D1), 2 (G1), 6 (O1), 8 (F1), 18 (T1), 2 (Ch1), 3 (M1) and 39 (P1). The genetic and physical distances between the Sen 1 and Sen 2 loci were indirectly estimated at $63 \mathrm{cM}$ and $32 \mathrm{Mbp}$, respectively (Plich et al., 2018).

Sen3 is a dominant monogenic locus of resistance to races 2, 6, and 18 (Prodhomme et al., 2019). Locus Sen18-IX (chromosome IX) determines resistance to race $18 \mathrm{~S}$. endobioticum, and locus Sen2/6/18-I (chromosome I) to races 2, 6, and 18. A. Ballvora et al. (2011) note that resistances to races 2, 6 and 18 correlate with each other, but are inherited regardless of resistance to race 1 .

Several markers have been developed to detect the dominant allele of the Sen1 gene: CP58, GP125 (Hehl et al., 1999), NL25 (Hehl et al., 1999; Bormann et al., 2004; Gebhardt et al., 2006), Sti046, St_At5g16710, GP125 and GP259 (Ballvora et al., 2011). Also, using a genome-wide association studies, a haplotype-specific marker PotVar0067008 associated with Sen 1 was identified (Prodhomme et al., 2020).

To identify the Sen18-IX locus, markers GP129, GP101 and STM3023b can be used. The Sen2/6/18-I locus can be diagnosed using markers STM2030, SC176, GP192, GP124, and GP194 (Ballvora et al., 2011). Markers Kc8103 and RK36, located on chromosome XI and linked to the Xla-TNL locus, have shown potential diagnostic value in determining resistance to races 18 and 6 of $S$. endobioticum (Bartkiewicz et al., 2018). Three markers, 5450_3, 2502_1, and 2502_3, linked to the Sen 2 locus were developed (Plich et al., 2018). It is possible to use the markers chr11_1259552 and chr11_1772869 to detect Sen3 (Prodhomme et al., 2019).

The aim of the study was to screen the GenAgro potato collection of the Institute of Cytology and Genetics of the Siberian Branch of the Russian Academy of Sciences (ICG SB RAS) using known diagnostic PCR markers linked to resistance to golden cyst potato nematode and potato wart. 


\section{Materials and methods}

Plant material. The research material was the collection of varieties and hybrids of potatoes named the "GenAgro" plant collection of the ICG SB RAS. The collection was represented by 73 varieties and hybrids of potatoes (Solanum tuberosum) (Supplement 1) ${ }^{1}$. The plants were grown in the field on the territory of the Michurinsky village, Novosibirsk region, from May to August 2017

Field tests were carried out according to the following scheme: the number of rows for each genotype was two; the number of plants in a row -10 ; row length $-3 \mathrm{~m}$; distance between the rows $-0.75 \mathrm{~m}$; distance between the plants in rows $-0.30 \mathrm{~m}$; planting method - manually (by hand) on furrows, filling furrows with harrows; landing date is the third decade of May.

Agrochemical characteristics of the soil: the content of exchanged potassium $110.00 \mathrm{mg} / \mathrm{kg}$; the amount of exchanged bases $24.19 \mathrm{mg}$-eq/100 g; hydrolytic acidity $3.23 \mathrm{mg}$-eq/100 g; exchanged acidity $5.60 \mathrm{mg}$-eq/100 g; humus content $2.67 \%$; the content of mobile phosphorus $5.14 \mathrm{mg} / \mathrm{kg}$; the degree of saturation with bases (V) $88.20 \%$.

Most of the data on resistance to PCN and potato wart were taken from references, namely from the database of the State Register of Selection Achievements Authorized for Use (State Register..., 2019; https://gossortrf.ru/), and from the European Cultivated Potato Database (https://www.europotato.org/). Some of the samples and hybrids for which there were no published data on resistance were evaluated under experimental conditions. Determination of resistance to PCN was carried out in accordance with the methodology recommended by OEPP/EPPO (2006) at the All-Russian Institute of Plant Protection. Potato wart resistance was evaluated according to the Glynn-Lemmerzahl method as described in the EPPO Diagnostic protocol for S. endobioticum (OEPP/EPPO, 2004) at the Russian Potato Research Center.

DNA isolation and PCR analysis. DNA was isolated from the skin of potato tubers using the DNeasy Plant Mini kit (Qiagen, CA, USA) according to the protocol. The concentration and purity of the tested samples were determined using gel electrophoresis and a Nanodrop 2000 apparatus.

Several diagnostic markers most often used in breeding programs were selected for genotyping (Table 1). These markers were associated with $R$-genes that determine resistance to race 1 of potato wart (S. endobioticum) and Ro1 pathotype of potato cyst nematode ( $G$. rostochiensis).

Two markers, 57R and CP113, associated with the $H 1$ resistance gene, and the Gro1-4 marker, associated with the Gro 1-4 resistance gene, were selected to identify PCN resistance genes (see Table 1). The SCAR PCR marker CP113-5'2/ CP113-3'2 was proposed by J. Niewöhner et al. (1995) based on the RFLP marker CP113. Amplification of DNA of resistant genotypes using this marker formed product with a $760 \mathrm{bp}$ length. The 57R marker was proposed by L. Schultz et al. (2012). Amplification of DNA of resistant genotypes formed product with a 450 bp length. SCAR PCR marker Gro1-4 was developed by J. Paal et al. (2004) based on the RFLP marker Gro1. Amplification of DNA of resistant genotypes formed product with a $602 \mathrm{bp}$ length.

1 Supplementary Materials are available in the online version of the paper: http://vavilov.elpub.ru/jour/manager/files/Suppl_Totsky_Engl.pdf
The NL25 marker was proposed by R. Hehl et al. (1999) when mapping the Sen 1 gene. C.A. Bormann et al. (2004) and C. Gebhardt et al. (2006) used this marker for markerassisted selection (see Table 1). Amplification produces one or two fragments of 1200 or $1400 \mathrm{bp}$ lenght. The presence of the dominant Sen 1 allele is determined by the presence of a $1400 \mathrm{bp}$ fragment.

PCR was carried out in a $20 \mu \mathrm{L}$ reaction mixture containing $100 \mathrm{ng}$ of DNA, $67 \mathrm{mM}$ Tris- $\mathrm{HCl}$ ( $\mathrm{pH} 8.8), 1.8 \mathrm{mM} \mathrm{MgCl}_{2}$, $0.01 \%$ Tween $20,0.2 \mathrm{mM}$ each dNTP, $0.25 \mu \mathrm{M}$ forward and reverse specific primers, 1 unit Taq DNA polymerase.

Two types of amplification programs (SSR55 and SSR60) represented the time-temperature profile of PCR. SSR55: (1) first cycle: $94{ }^{\circ} \mathrm{C}-2 \mathrm{~min}$; (2) the next 45 cycles: $94{ }^{\circ} \mathrm{C}-$ 1 minute, $55^{\circ} \mathrm{C}-1$ minute and $72{ }^{\circ} \mathrm{C}-2$ minutes; (3) one cycle of 5 minutes at $72{ }^{\circ} \mathrm{C}$ (Gro1-4). SSR60: (1) first cycle: $94{ }^{\circ} \mathrm{C}-2 \mathrm{~min}$; (2) the next 45 cycles: $94^{\circ} \mathrm{C}-1$ minute, $60^{\circ} \mathrm{C}-$ 1 minute and $72{ }^{\circ} \mathrm{C}-2$ minutes; (3) one cycle of 5 minutes at $72{ }^{\circ} \mathrm{C}(\mathrm{NL} 25, \mathrm{CP} 113,57 \mathrm{R})$.

The analysis of the obtained PCR products was carried out by electrophoresis in a $2 \%$ agarose gel. The results were documented using a Molecular Imager Gel Doc XR System (BioRad) using UV light.

Statistical processing of the data was carried out using Spearman's correlation coefficient; for calculations, the STATISTICA program was used. The diagnostic efficiency, sensitivity, specificity and predictive value were calculated using the MedCalc software (https://www.medcalc.org/). Diagnostic efficiency was defined as the proportion of correct test results in the total number of test results, or the sum of true positive and true negative test results divided by the total number of test results. The sensitivity was calculated as the number of resistant samples identified using a DNA marker divided by the total number of resistant samples. Specificity is the number of susceptible samples identified by the DNA marker divided by the total number of susceptible samples. Positive predictive value was defined as the proportion of correct positive diagnostic test results.

\section{Results}

Among 73 samples selected for genotyping, 35 were resistant to PCN, 37 samples were susceptible, and in one sample, resistance to nematodes was unknown (Table 2). 69 samples were resistant to wart, 3 samples were susceptible to disease, the resistance of one sample was unknown (see Table 2).

\section{Genotyping of varieties and hybrids using markers designed for resistance to PCN}

The $57 \mathrm{R}$ marker is found in $85.7 \%$ of resistant samples, as well as in $13.5 \%$ of susceptible ones (Table 3; Supplement 2, Fig. 1-6; Supplement 3). Some mismatches can be observed due to the absence of linkage of the 57R marker with the $H 1$ resistance gene in a number of samples. The second reason for the mismatches can be explained by the presence of other resistance genes in samples that do not carry the 57R marker. The diagnostic efficiency of the 57R marker, which is expressed as the percentage of true (both positive and negative) test results to the total number of results obtained, was $86.11 \%$. The diagnostic sensitivity of the used marker, which shows the number of resistant samples identified using the DNA marker 
Table 1. DNA markers used for collection screening

\begin{tabular}{|c|c|c|c|c|c|c|}
\hline Gene & Trait & $\begin{array}{l}\text { Marker } \\
\text { and primer } \\
\text { name }\end{array}$ & $\begin{array}{l}\text { Nucleotide sequence } \\
\text { from } 5^{\prime} \text { to } 3^{\prime}\end{array}$ & $\begin{array}{l}\text { Gene } \\
\text { localization }\end{array}$ & $\begin{array}{l}\text { Diagnostic } \\
\text { fragment size, bp }\end{array}$ & Reference \\
\hline \multirow[t]{4}{*}{$H 1$} & \multirow{4}{*}{$\begin{array}{l}\text { Resistance } \\
\text { to golden potato } \\
\text { cyst nematode } \\
\text { (G. rostochiensis) }\end{array}$} & CP113F & GCGTTACAGTCGCCGTAT & \multirow[t]{4}{*}{ Chromosome V } & 760 & \multirow{2}{*}{$\begin{array}{l}\text { Niewöhner et al., } \\
1995\end{array}$} \\
\hline & & CP113R & GTTGAAGAAATATGGAATCAAA & & & \\
\hline & & $57 R-F$ & TGCCTGCCTCTCCGATTTCT & & 450 & Schultz et al., 2012 \\
\hline & & $57 R-R$ & GGTTCAGCAAAAGCAAGGACGTG & & & \\
\hline \multirow[t]{2}{*}{ Gro 1-4 } & & Gro1-4F & TCTTTGGAGATACTGATTCTCA & \multirow[t]{2}{*}{ Chromosome VII } & 602 & \multirow[t]{2}{*}{ Paal et al., 2004} \\
\hline & & Gro1-4R & CGACCTAAAATGAAAAGCATCT & & & \\
\hline \multirow[t]{2}{*}{$\operatorname{Sen} 1$} & \multirow{2}{*}{$\begin{array}{l}\text { Resistance } \\
\text { to wart (pathogen - } \\
\text { S. endobioticum) }\end{array}$} & NL25F & TATTGTTAATCGTTACTCCCTC & \multirow[t]{2}{*}{ Chromosome XI } & 1400 & \multirow{2}{*}{$\begin{array}{l}\text { Hehl et al., 1999; } \\
\text { Bormann et al., 2004; } \\
\text { Gebhardt et al., } 2006\end{array}$} \\
\hline & & NL25R & AGAGTCGTTTTACCGACTCC & & & \\
\hline
\end{tabular}

divided by the total number of resistant samples, was $85.71 \%$. The diagnostic specificity, which is the number of susceptible samples identified by the DNA marker divided by the total number of susceptible samples, was $86.48 \%$. The predictive value of a positive result, showing the proportion of correct positive diagnostic test results, was $85.71 \%$. Calculation of the Spearman correlation coefficient (Spearman $\mathrm{R}=0.722008$, $p=0.000000, p<0.05)$ showed a significant correlation between resistance and the $57 \mathrm{R}$ marker.

The CP113 marker is found in only $48.6 \%$ of resistant accessions, while the marker is present in $62.9 \%$ of susceptible genotypes (see Table 3; Supplement 2, Fig. 7; Supplement 3). These results can be regarded as the absence of linkage of the marker with the $H 1$ resistance gene in many samples of the potato collection. The diagnostic efficiency of the CP113 marker was only $44.44 \%$. Diagnostic sensitivity was $48.57 \%$. Diagnostic specificity accounted for $40.54 \%$. The predictive value of a positive result, indicating the probability of resistance presence if the test shows a positive result when CP113 marker was used, was equal to $43.58 \%$. Spearman's correlation coefficient (Spearman $\mathrm{R}=-0.109218, p=0.361104, p<0.05$ ) in this case showed no significant correlation between resistance and DNA marker. The use of such a marker when screening a population to search for resistant samples is not advisable.

29 samples were analyzed using the Gro1-4 marker. The diagnostic fragment was amplified in only 5 samples. Correspondence of the presence of the marker in the resistant sample was observed only in 1 case out of 5 . In other cases, the marker was found in the samples susceptible to the disease.

The data obtained show that when screening populations for resistance to $\mathrm{PCN}$, it is advisable to use the 57R marker.

\section{Genotyping of varieties and hybrids using markers linked to resistance to potato wart}

The NL25 marker is found in $62.3 \%$ of resistant samples, however, the marker is present in two of the three susceptible genotypes (see Table 3, Supplement 4). This can be explained by the processes of crossing over and by the fact that in a number of samples the linkage of the marker and the resistance gene is not observed; however, the small number of sensitive samples does not allow sufficiently assessing the applicability of the marker for breeding. The marker is absent in 27 samples and only in one case we observe the absence of a marker in the susceptible sample, in the other cases the marker is absent in the resistant samples. This can be explained by the presence of another resistance gene that is not linked to the NL25 marker.

The diagnostic efficiency of resistance using the NL25 marker was $61.11 \%$. The diagnostic sensitivity turned out to be at $62.31 \%$. The diagnostic specificity was only $33.33 \%$. However, the predictive value of a positive result, showing the proportion of correct positive diagnostic test results, when using the NL25 marker was equal to $95.55 \%$. It should be noted that such results are associated with the fact that the set of samples contained only three sensitive samples, and two of them showed the presence of the NL25 marker. Spearman's correlation coefficient (Spearman $\mathrm{R}=-0.017946$, $p=0.881061, p<0.05)$ in such situation showed the absence of significant correlations.

Despite the fact that the NL25 marker is often used in screening and marker selection, a study in our set of samples showed that its use does not guarantee a reliable result.

\section{Discussion}

In our study, 13 resistant to golden potato nematode samples that had both markers (57R and CP113) linked to the H1 nematode resistance gene were found. In addition, there are 8 genotypes resistant to nematodes and wart and carrying both the 57R and CP113 markers linked to the $H 1$ nematode resistance gene and the NL25 marker linked to the Sen1 wart resistance gene. There is also one sample (Safo) in the population that is resistant to wart and nematodes and carries all three markers 57R, CP113, Gro1-4, linked to nematode resistance, and marker NL25, linked to wart resistance.

\section{DNA markers of wart resistance}

The NL25 marker linked to the Sen 1 gene, which provides resistance to pathotype 1 of potato wart, is successfully used in the practice of marker-oriented selection. So, C. Gebhardt and colleagues reported that after screening 17 plants in two families of segregating populations using the NL25 marker, 
Table 2. Resistance of varieties and hybrids of potatoes to nematodes and wart

\begin{tabular}{|c|c|c|c|c|c|c|c|}
\hline No. & Variety/hybrid & $\begin{array}{l}\text { Resistance } \\
\text { to golden potato } \\
\text { cyst nematode }\end{array}$ & $\begin{array}{l}\text { Resistance } \\
\text { to wart }\end{array}$ & No. & Variety/hybrid & $\begin{array}{l}\text { Resistance } \\
\text { to golden potato } \\
\text { cyst nematode }\end{array}$ & $\begin{array}{l}\text { Resistance } \\
\text { to wart }\end{array}$ \\
\hline 1 & Fregata & $+^{2}$ & $t^{2}$ & 38 & Lomonosovskij & -1 & $+^{1}$ \\
\hline 2 & Agata & $t^{2}$ & $t^{2}$ & 39 & Lyubava & -1 & $+^{1}$ \\
\hline 3 & Alyona & -1 & $+^{1}$ & 40 & Lyuks & $+^{1}$ & $+{ }^{1}$ \\
\hline 4 & Antonina & -1 & $+^{1}$ & 41 & Maret & $+^{1}$ & NA \\
\hline 5 & Aroza & $+^{1}$ & $+^{1}$ & 42 & Matushka & -1 & $+{ }^{1}$ \\
\hline 6 & Bozhedar & NA & $+^{1}$ & 43 & Meteor & $+^{1}$ & $+^{1}$ \\
\hline 7 & Bravo & $+^{1}$ & $+^{1}$ & 44 & Monaliza & $-{ }^{1}$ & $++^{1}$ \\
\hline 8 & Vasilyok & -1 & $+^{1}$ & 45 & Nakra & -1 & $+{ }^{1}$ \\
\hline 9 & Velikan & -1 & $+^{1}$ & 46 & Nayada & $+^{1}$ & $+{ }^{1}$ \\
\hline 10 & Virazh & $+^{1}$ & $+^{1}$ & 47 & Nevskij & $-{ }^{1}$ & $++^{1}$ \\
\hline 11 & Vympel & $+^{1}$ & $+^{1}$ & 48 & Nikulinskij & -1 & $+^{1}$ \\
\hline 12 & Gala & $+{ }^{1}$ & $+^{1}$ & 49 & Pamyati Osipovoj & $-{ }^{1}$ & $+^{1}$ \\
\hline 13 & Golubizna & -1 & $+^{1}$ & 50 & Pamyati Rogachyova & -1 & $+^{1}$ \\
\hline 14 & Gornyak & -1 & $+^{1}$ & 51 & Pikasso & $+^{1}$ & $++^{1}$ \\
\hline 15 & Granat & $--^{2}$ & $+^{2}$ & 52 & Reggi & -1 & $+^{1}$ \\
\hline 16 & Granola & $+^{2}$ & $--^{2}$ & 53 & Red Skarlet & $+^{1}$ & $++^{1}$ \\
\hline 17 & Gulliver & $+{ }^{1}$ & $+^{1}$ & 54 & Safo & $+^{1}$ & $+^{1}$ \\
\hline 18 & Gusar & $++^{1}$ & $+^{1}$ & 55 & Favorit & $+^{1}$ & $t^{1}$ \\
\hline 19 & Debryansk & -1 & $+^{1}$ & 56 & Fioletovyj & -1 & $+^{1}$ \\
\hline 20 & Diamant & $+^{2}$ & $t^{2}$ & 57 & Fritella & -1 & $+^{1}$ \\
\hline 21 & Zhigulyovskij & -1 & $+^{1}$ & 58 & Yuna & $+^{1}$ & $+^{1}$ \\
\hline 22 & Zhukovskij rannij & $+{ }^{1}$ & $+^{1}$ & 59 & $1-7-5 A$ & -3 & $++^{4}$ \\
\hline 23 & Zagadka & $+^{1}$ & $+^{1}$ & 60 & $(1-9-2)$ & -3 & $+^{4}$ \\
\hline 24 & Zekura & $+^{1}$ & $+^{1}$ & 61 & $2-5-4 B$ & -3 & $+^{4}$ \\
\hline 25 & Zlatka & -1 & $+^{1}$ & 62 & $1-14-2 A$ & $t^{3}$ & $++^{4}$ \\
\hline 26 & Il'inskij & -1 & $+^{1}$ & 63 & $1014 / 3-1$ & $t^{3}$ & $+^{4}$ \\
\hline 27 & Impala & $+{ }^{1}$ & $+^{1}$ & 64 & $821 / 1-5$ & $t^{3}$ & $++^{4}$ \\
\hline 28 & Irbitskij & $+^{1}$ & $+^{1}$ & 65 & 419/8-1 & -3 & $+^{4}$ \\
\hline 29 & Kemerovchanin & $+^{1}$ & $+^{1}$ & 66 & $1014 / 8-1$ & $t^{3}$ & $+^{4}$ \\
\hline 30 & Klada & $--^{2}$ & $+^{2}$ & 67 & $1013 / 3-1$ & $t^{3}$ & $+^{4}$ \\
\hline 31 & Koldovskaya & $--^{3}$ & -4 & 68 & $790 / 1-5$ & -3 & $+^{4}$ \\
\hline 32 & Kolobok & -1 & $+^{1}$ & 69 & $(2-5-2)$ & $t^{3}$ & $+^{4}$ \\
\hline 33 & Kortni & $+^{1}$ & $+^{1}$ & 70 & $785 / 8-5$ & -3 & $+^{4}$ \\
\hline 34 & Krepysh & $+^{1}$ & $+^{1}$ & 71 & $999 / 1-1$ & -3 & $+^{4}$ \\
\hline 35 & Kuznechanka & -1 & $+^{1}$ & 72 & $597 / 4-1$ & -3 & -4 \\
\hline 36 & Ladozhskij & $+^{1}$ & $+^{1}$ & 73 & $417 / 2$ & -3 & $+^{4}$ \\
\hline 37 & Lina & -1 & $+^{1}$ & & & & \\
\hline
\end{tabular}

Note. 1 State Register of Selection Achievements Authorized for Use; 2 The European Cultivated Potato Database; ${ }^{3}$ All-Russian Institute of Plant Protection;

${ }^{4}$ Russian Potato Research Center; NA - no data. 
Table 3. Results of screening of potato cultivars and hybrids collection for PCN resistance using the 57R marker and for wart resistance using the NL25 marker

\begin{tabular}{|c|c|c|c|}
\hline Disease resistance & Marker is present & Marker is missing & Diagnostic efficiency, \% \\
\hline \multicolumn{4}{|c|}{ Marker 57R } \\
\hline PCN resistant sample & 30 & 5 & 86.11 \\
\hline PCN susceptible sample & 5 & 32 & \\
\hline \multicolumn{4}{|c|}{ Marker CP113 } \\
\hline PCN resistant sample & 17 & 18 & 44.44 \\
\hline PCN susceptible sample & 22 & 15 & \\
\hline \multicolumn{4}{|c|}{ Marker NL25 } \\
\hline PCN resistant sample & 43 & 26 & 61.11 \\
\hline PCN susceptible sample & 2 & 1 & \\
\hline
\end{tabular}

14 genotypes with the marker were identified. All these plants were found to be resistant to pathotype $1 \mathrm{~S}$. endobioticum. Some were also resistant to pathotype 2 and/or pathotype 6 (Gebhardt et al., 2006).

The effectiveness of this marker is also reported by O.Y.Antonova and colleagues who analyzed 98 varieties using the NL25 marker. A diagnostic component was found in 95 studied wart-resistant varieties, while it was not found in three susceptible varieties. This shows a high level of correlation between the presence or absence of the marker and the resistance and sensitivity of the genotype to wart, respectively (Antonova et al., 2016).

However, A. Khiutti and colleagues, when screening 52 genotypes using the NL25 marker, found that 39 samples (both sensitive and resistant genotypes) had the same nondiagnostic fragment, 12 genotypes did not have amplification of the NL25 marker fragments. Only 5 out of 52 genotypes had a diagnostic fragment indicating the presence of a resistance gene. Four of these five accessions were resistant, but one genotype was found to be sensitive; most resistant genotypes did not have a 1400 bp diagnostic fragment predicting a resistant phenotype (Khiutti et al., 2012).

Our analysis also did not allow us to speak about the reliability of using the NL25 marker for screening resistant varieties.

\section{DNA markers of resistance to PCN}

Using the Gro1-4 marker in a segregating population, C. Gebhardt and colleagues found that all 45 plants carrying this marker linked to the Grol gene were resistant to the Rol pathotype of G. rostochiensis (Gebhardt et al., 2006).

C. Gebhardt and colleagues in 1993 found in a segregating population that the CP113 marker is linked to the $H 1$ gene so strongly that it has zero recombination (Gebhardt et al., 1993). However, D. Milczarek and colleagues (2011) reported that the CP113 marker was amplified for all tested varieties, resistant and sensitive, and was unsuitable for the selection of resistant clones. A similar picture is observed in our work.

The 57R SCAR marker was tested in a mapping population, where it was linked to the $H 1$ locus and nematode resistance (Finkers-Tomczak et al., 2011). Later L. Schultz and colleagues reported that they analyzed two independent populations of 281 and 122 potato samples with known resistance/sensitivity using the 57R SCAR marker. When screening the first population, the 57R marker revealed a correspondence between genotype and phenotype, 89 out of 90 resistant varieties had an allele associated with resistance. Only one resistant variety, in which no marker amplification was observed, became an exception. None of the 191 PCN susceptible varieties had an allele predicting resistance. Then another independent population of 122 varieties was screened. All varieties showed complete correspondence between resistance to $G$. rostochiensis and the presence/absence of the $57 \mathrm{R}$ allele, corresponding to the presence of the resistance gene (Schultz et al., 2012).

O.Y. Antonova et al. (2016) identified the 57R marker in $33(30.3 \%)$ of 109 breeding varieties they studied. The overwhelming majority of the varieties with the diagnosed 57R fragment were resistant or weakly affected by the nematode. The correspondence between resistance and the presence of a diagnostic fragment was high $-93.5 \%$. At the same time, only four genotypes with the Gro1-4 marker were identified: two resistant varieties, one weakly affected variety and one susceptible. All these four varieties, along with the Gro1-4 marker, also possessed the $H 1$ gene markers - 57R, TG689, N146, N195 (Antonova et al., 2016).

In the work of N.S. Klimenko et al. (2017) showed the presence of the 57R marker in 24 out of 103 samples, while the marker was found in 15 resistant and 2 susceptible samples. It was shown that the correlation between the presence of at least one marker of the $H 1$ gene and the data on the nematode resistance of varieties was +0.92 (Klimenko et al., 2017).

T.A. Gavrilenko et al. (2018) showed that out of 39 samples of the studied set of samples, 15 had a dominant allele of the $H 1$ gene (based on a number of DNA markers), and two varieties had dominant alleles of both $\mathrm{Hl}$ and Grol-4 genes. At the same time, none of the markers was identified in the remaining 22 genotypes. Comparison of these results with resistance to G. rostochiensis (pathotype Ro1) showed that all accessions with $H 1$ gene markers are nematode resistant, while varieties affected by $G$. rostochiensis did not have these markers (Gavrilenko et al., 2018). This high correlation shows 
the reliability of the markers used in the study, which can be used to select resistant samples.

It should be noted that the saturation of the genotype with genes of resistance to the nematode does not affect its economically valuable traits. At the same time, there is a strong link between the presence of the marker and resistance. So, in the study of D. Milczarek and colleagues in 2014, the relationship between the presence of markers TG689 and 57R linked to the $H 1$ gene, which determines resistance to the nematode G. rostochiensis, and valuable agricultural traits is presented. Clones with these markers had a higher total yield of tubers and total starch yield than clones without markers. There was no negative association between marker presence and quality. All 347 seedlings obtained after three crosses were genotyped using both markers and phenotypically evaluated for resistance to the Rol pathotype of $G$. rostochiensis. Of these, 316 (i. e. $91 \%$ ) and 325 (94\%) clones were resistant and carried the TG689 or 57R markers (Milczarek et al., 2014).

\section{Conclusion}

In general, our data on the 57R marker are quite close to the results described above and confirm the high reliability of the work of this marker, which suggests the need to use this marker when selecting samples resistant to PCN.

\section{References}

Antonova O.Y., Shvachko N.A., Novikova L.Y., Shuvalov O.Y., Kostina L.I., Klimenko N.S., Shuvalova A.R., Gavrilenko T.A. Genetic diversity of potato varieties bred in Russia and its neighboring countries based on the polymorphism of SSR-loci and markers associated with resistance R-genes. Russ. J. Genet. Appl. Res. 2017;7(5):489500. DOI 10.1134/S2079059717050021.

Asano K., Kobayashi A., Tsuda S., Nishinaka M., Tamiya S. DNA marker-assisted evaluation of potato genotypes for potential resistance to potato cyst nematode pathotypes not yet invading into Japan. Breed. Sci. 2012;62(2):142-150. DOI 10.1270/jsbbs.62.142.

Baayen R.P., Cochius G., Hendriks H., Meffert J.P., Bakker J., Bekker M., van den Boogert P.H.J.F., Stachewicz H., van Leeuwen G.C.M. History of potato wart disease in Europe - a proposal for harmonisation in defining pathotypes. Eur. J. Plant Pathol. 2006;116(1):21-31. DOI 10.1007/s10658-006-9039-y.

Bakker E., Achenbach U., Bakker J., van Vliet J., Peleman J., Segers B., van der Heijden S., van der Linde P., Graveland R., Hutten R., van Eck H., Coppoolse E., van der Vossen E., Bakker J., Goverse A. A high-resolution map of the $H 1$ locus harbouring resistance to the potato cyst nematode Globodera rostochiensis. Theor. Appl. Genet. 2004;109(1):146-152. DOI 10.1007/s00122-004-1606-z. Epub 2004 Feb 25.

Ballvora A., Flath K., Lubeck J., Strahwald J., Tacke E., Hofferbert H.-R., Gebhardt C. Multiple alleles for resistance and susceptibility modulate the defense response in the interaction of tetraploid potato (Solanum tuberosum) with Synchytrium endobioticum pathotypes 1, 2, 6 and 18. Theor. Appl. Genet. 2011;123(8):1281-1292. DOI 10.1007/s00122-011-1666-9. Epub 2011 Aug 6.

Ballvora A., Hesselbach J., Niewöhner J., Leister D., Salamini F., Gebhardt C. Marker enrichment and high-resolution map of the segment of potato chromosome VII harbouring the nematode resistance gene Gro1. Mol. General Genet. 1995;249:82-90. DOI 10.1007/ BF00290239.

Barone A., Ritter E., Schachtschabel U., Debener T., Salamini F., Gebhardt C. Localization by restriction fragment length polymorphism mapping in potato of a major dominant gene conferring resistance to the potato cyst nematode Globodera rostochiensis. Mol. General Genet. 1990;224(2):177-182. DOI 10.1007/BF00271550.
Bartkiewicz A., Chilla F., Terefe-Ayana D., Lübeck J., Strahwald J., Tacke E., Hoferbert H.-R., Flath K., Linde M., Debener T. Improved genetic resolution for linkage mapping of resistance to potato wart in monoparental dihaploids with potential diagnostic value in tetraploid potato varieties. Theor. Appl. Genet. 2018;131:2555-2566. DOI 10.1007/s00122-018-3172-9.

Bormann C.A., Rickert A.M., Ruiz R.A.C., Paal J., Lübeck J., Strahwald J., Buhr K., Gebhardt C. Tagging quantitative trait loci for maturity-corrected late blight resistance in tetraploid potato with PCR-based candidate gene markers. Mol. Plant-Microbe Interact. 2004;17(10):1126-1138. DOI 10.1094/MPMI.2004.17.10.1126.

Brugmans B., Hutten R.G.B., Rookmaker N., Visser R.G.F., van Eck H.J. Exploitation of a marker dense linkage map of potato for positional cloning of a wart disease resistance gene. Theor. Appl. Genet. 2006;112(2):269-277. DOI 10.1007/s00122-005-0125-x.

Finkers-Tomczak A., Bakker E., Boer J., Vossen E., Achenbach U., Golas T., Suryaningrat S., Smant G., Bakker J., Goverse A. Comparative sequence analysis of the potato cyst nematode resistance locus $H 1$ reveals a major lack of co-linearity between three haplotypes in potato (Solanum tuberosum ssp.). Theor. Appl. Genet. 2011;122: 595-608. DOI 10.1007/s00122-010-1472-9.

Finkers-Tomczak A., Danan S., van Dijk T., Beyene A., Bouwman L., Overmars H., van Eck H., Goverse A., Bakker J., Bakker E. A highresolution map of the Grpl locus on chromosome V of potato harbouring broad-spectrum resistance to the cyst nematode species Globodera pallida and Globodera rostochiensis. Theor. Appl. Genet. 2009;119(1):165-173. DOI 10.1007/s00122-009-1026-1.

Flor H.H. Current status of the gene-for-gene concept. Annu. Rev. Phytopathol. 1971;9:275-296. DOI 10.1146/annurev.py.09.090171. 001423.

Food and Agriculture Organization of the United Nations. World Food and Agriculture - Statistical pocketbook 2019. Rome: FAO, 2019. Available at: http://www.fao.org/3/ca6463en/ca6463en.pdf.

Galek R., Rurek M., De Jong W.S., Pietkiewicz G., Augustyniak H., Sawicka-Sienkiewicz E. Application of DNA markers linked to the potato $\mathrm{H} 1$ gene conferring resistance to pathotype Ro1 of Globodera rostochiensis. J. Appl. Genet. 2011;52(4):407-411. DOI 10.1007/ s13353-011-0056-y.

Gavrilenko T.A., Klimenko N.S., Antonova O.Yu., Lebedeva V.A., Evdokimova Z.Z., Gadjiyev N.M., Apalikova O.V., Alpatyeva N.V., Kostina L.I., Zoteyeva N.M., Mamadbokirova F.T., Egorova K.V. Molecular screening of potato varieties bred in the northwestern zone of the Russian Federation. Vavilovskii Zhurnal Genetiki i Selektsii = Vavilov Journal of Genetics and Breeding. 2018;22(1):35-45. DOI 10.18699/VJ18.329. (in Russian)

Gebhardt C., Ballvora A., Walkemeier B., Oberhagemann P., Schüler K. Assessing genetic potential in germplasm collections of crop plants by marker-trait association: a case study for potatoes with quantitative variation of resistance to late blight and maturity type. Mol. Breed. 2004;13:93-102. DOI 10.1023/B:MOLB.0000012878.89855.df.

Gebhardt C., Bellin D., Henselewski H., Lehmann W., Schwarzfischer J., Valkonen J. Marker-assisted combination of major genes for pathogen resistance in potato. Theor. Appl. Genet. 2006; 112(8):1458-1464. DOI 10.1007/s00122-006-0248-8. Epub 2006 Mar 15.

Gebhardt C., Mugniery D., Ritter E., Salamini F., Bonnel E. Identification of RFLP markers closely linked to the $H 1$ gene conferring resistance to Globodera rostochiensis in potato. Theor. Appl. Genet. 1993;85:541-544. DOI 10.1007/BF00220911.

Gebhardt C., Valkonen J.P.T. Organization of genes controlling disease resistance in the potato genome. Annu. Rev. Phytopathol. 2001;39: 79-102. DOI 10.1146/annurev.phyto.39.1.79.

Groth J., Song Y., Kellermann A., Schwarzfischer A. Molecular characterisation of resistance against potato wart races 1, 2, 6 and 18 in a tetraploid population of potato (Solanum tuberosum subsp. tuberosum). J. Appl. Genet. 2013;54(2):169-178. DOI 10.1007/ s13353-013-0141-5. Epub 2013 Feb 24. 
Hampson M.C. History, biology and control of potato wart disease in Canada. Can. J. Plant Pathol. 1993;15(4):223-244. DOI 10.1080/ 07060669309501918 .

Hehl R., Faurie E., Hesselbach J., Salamini F., Whitham S., Baker B., Gebhardt C. TMV resistance gene $N$ homologues are linked to Synchytrium endobioticum resistance in potato. Theor. Appl. Genet. 1999;98:379-386. DOI 10.1007/s001220051083.

Jacobs J.M.E., Eck H.J., Horsman K., Arens P.F.P., Verkerk-Bakker B., Jacobsen E., Pereira A., Stiekema W.J. Mapping of resistance to the potato cyst nematode Globodera rostochiensis from the wild potato species Solanum vernei. Mol. Breed. 1996;2:51-60. DOI 10.1007/ BF00171351.

Janssen R., Bakker J., Gommers F.J. Mendelian proof for a gene-forgene relationship between virulence of Globodera rostochiensis and the $H 1$ resistance gene in Solanum tuberosum ssp. andigena CPC 1673. Rev. de Nematol. 1991;14(2):207-211.

Jones F.G.W., Parrott D.M., Perry J.N. The gene-for-gene relationship and its significance for potato cyst nematodes and their solanaceous hosts. In: Zuckerman B.M., Rohde R.A. (Eds.). Plant Parasitic Nematodes. Vol. 3. New York: Acad. Press, 1981;23-36.

Khiutti A., Afanasenko O., Antonova O., Shuvalov O., Novikova L., Krylova E., Chalaya N., Mironenko N., Spooner D., Gavrilenko T. Characterization of resistance to Synchytrium endobioticum in cultivated potato accessions from the collection of Vavilov Institute of Plant Industry. Plant Breed. 2012;131(6):744-750. DOI 10.1111/ j.1439-0523.2012.02005.x.

Khiutti A.V., Antonova O.Yu., Mironenko N.V., Gavrilenko T.A., Afanasenko O.S. Potato resistance to quarantine diseases. Russ. J. Genet. Appl. Res. 2017;7(8):833-844. DOI 10.1134/S20790597170 50094.

Klimenko N.S., Antonova O.Yu., Kostina L.I., Mamadbokirova F.T., Gavrilenko T.A. Marker-assisted selection of Russian potato varieties with markers of genes for resistance to potato golden nematode (pathotype Ro1). Trudy po Prikladnoy Botanike, Genetike i Selektsii $=$ Proceedings on Applied Botany, Genetics, and Breeding. 2017;178(4):66-75. DOI 10.30901/2227-8834-2017-4-66-75. (in Russian)

Koretsky P.M. Harmfulness of potato wart in household plots in areas of widespread of the disease in Ukraine. Mikologiya $i$ Fitopatologiya $=$ Mycology and Phytopathology. 1970;4(4):366-369. (in Russian)

Kort J., Stone A.R., Rumpenhorst H.J., Ross H. An international scheme for identifying and classifying pathotypes of potato cyst-nematodes Globodera rostochiensis and G. pallida. Nematologica. 1977;23(3): 333-339. DOI 10.1163/187529277x00057.

Kreike C.M., De Koning J.R.A., Vinke J.H., Van Ooijen J.W., Stiekema W.J. Mapping of loci involved in quantitatively inherited resistance to the potato cyst-nematode Globodera rostochiensis pathotype Ro1. Theor. Appl. Genet. 1993;87:464-470. DOI 10.1007/ BF00215092.

Kreike C.M., Kok-Westeneng A.A., Vinke J.H., Stiekema W.J. Mapping of QTLs involved in nematode resistance, tuber yield and root development. Theor. Appl. Genet. 1996;92:463-470. DOI 10.1007/ BF00223694.

Kuhl J.C. Mapping and tagging of simply inherited traits. In: Bradeen J.M., Chittaranjan K. (Eds.). Genetics, Genomics and Breeding of Potato. Enfield, New Hampshire: Sci. Publishers, 2011;90-112.

Leister D., Ballvora A., Salamini F., Gebhardt C. A PCR based approach for isolating pathogen resistance genes from potato with potential for wide application in plants. Nat. Genet. 1996;14:421-429. DOI 10.1038/ng1296-421.

Limantseva L., Mironenko N., Shuvalov O., Antonova O., Khiutti A., Novikova L., Afanasenko O., Spooner D., Gavrilenko T. Characterization of resistance to Globodera rostochiensis pathotype Rol in cultivated and wild potato species accessions from the Vavilov Institute of Plant Industry. Plant Breed. 2014;133(5):660-665. DOI 10.1111/pbr.12195.
Lopez-Pardo R., Barandalla L., Ritter E., de Galarreta J.I.R. Validation of molecular markers for pathogen resistance in potato. Plant Breed. 2013;132:246-251. DOI 10.1111/pbr.12062.

Milczarek D., Flis B., Przetakiewicz A. Suitability of molecular markers for selection of potatoes resistant to Globodera spp. Am. J. Potato Res. 2011;88:245-255. DOI 10.1007/s12230-011-9189-0.

Milczarek D., Przetakiewicz A., Kaminski P., Flis B. Early selection of potato clones with the $\mathrm{Hl}$ resistance gene - the relation of nematode resistance to quality characteristics. Czech J. Genet. Plant Breed. 2014;50(4):278-284. DOI 10.17221/114/2014-CJGPB.

Mori K., Sakamoto Y., Mukojima N., Tamiya S., Nakao T., Ishii T., Hosaka K. Development of a multiplex PCR method for simultaneous detection of diagnostic DNA markers of five disease and pest resistance genes in potato. Euphytica. 2011;180:347-355. DOI 10.1007/ s10681-011-0381-6.

Niewöhner J., Salamini F., Gebhardt C. Development of PCR assays diagnostic for RFLP marker alleles closely linked to alleles Grol and $H 1$, conferring resistance to the root cyst nematode Globodera rostochiensis in potato. Mol. Breed. 1995;1:65-78. DOI 10.1007/ BF01682090.

Obidiegwu J.E., Flath K., Gebhardt C. Managing potato wart: a review of present research status and future perspective. Theor. Appl. Genet. 2014;127(4):763-780. DOI 10.1007/s00122-014-2268-0.

Obidiegwu J.E., Sanetomo R., Flath K., Tacke E., Hoferbert H.-R., Hofmann A., Walkemeier B., Gebhardt C. Genomic architecture of potato resistance to Synchytrium endobioticum disentangled using SSR markers and the $8.3 \mathrm{k}$ SolCAP SNP genotyping array. BMC Genet. 2015;16:38. DOI 10.1186/s12863-015-0195-y.

OEPP/EPPO Standards PM 7/28. Diagnostic protocols for regulated pests: Synchytrium endobioticum. Bulletin OEPP/EPPO Bulletin. 2004;34:213-218. DOI 10.1111/j.1365-2338.2004.00722.x.

OEPP/EPPO Testing of potato varieties to assess resistance to Globodera rostochiensis and Globodera pallida. Bulletin OEPP/ EPPO Bulletin. 2006;36:419-420. DOI 10.1111/j.1365-2338.2006. 01032.x.

Paal J., Henselewski H., Muth J., Meksem K., Menéndez C.M., Salamini F., Ballvora A., Gebhardt C. Molecular cloning of the potato Grol-4 gene conferring resistance to pathotype Rol of the root cyst nematode Globodera rostochiensis, based on a candidate gene approach. Plant J. 2004;38(2):285-297. DOI 10.1111/j.1365313X.2004.02047.x.

Pajerowska-Mukhtar K., Stich B., Achenbach U., Ballvora A., Lübeck J., Strahwald J., Tacke E., Hofferbert H.-R., Ilarionova E., Bellin D., Walkemeier B., Basekow R., Kersten B., Gebhardt C. Single nucleotide polymorphisms in the allene oxide synthase 2 gene are associated with field resistance to late blight in populations of tetraploid potato cultivars. Genetics. 2009;181(3):1115-1127. DOI 10.1534/genetics.108.094268.

Pineda O., Bonierbale M.W., Plaisted R.L., Brodie B.B., Tanksley S.D. Identification of RFLP markers linked to the $H 1$ gene conferring resistance to the potato cyst nematode Globodera rostochiensis. Genome. 1993;36(1):152-156. DOI 10.1139/g93-019.

Plich J., Przetakiewicz J., Śliwka J., Flis B., Wasilewicz-Flis I., Zimnoch-Guzowska E. Novel gene Sen 2 conferring broad-spectrum resistance to Synchytrium endobioticum mapped to potato chromosome XI. Theor. Appl. Genet. 2018;131:2321-2331. DOI 10.1007/ s00122-018-3154-y.

Prodhomme C., Esselink D., Borm T., Visser R.G.F., van Eck H.J., Vossen J.H. Comparative Subsequence Sets Analysis (CoSSA) is a robust approach to identify haplotype specific SNPs; mapping and pedigree analysis of a potato wart disease resistance gene Sen3. Plant Methods. 2019;15:60. DOI 10.1186/s13007-019-0445-5.

Prodhomme C., Peter G.V., Paulo M.J., Visser R.G.F., Vossen J.H., van Eck J.H. Distribution of P1(D1) wart disease resistance in potato germplasm and GWAS identification of haplotype-specific SNP markers. Theor. Appl. Genet. 2020;133:1859-1871. DOI 10.1007/ s00122-020-03559-3. 
Ramakrishnan A.P., Ritland C.E., Blas Sevillano R.H., Riseman A. Review of potato molecular markers to enhance trait selection. Am. J. Potato Res. 2015;92(4):455-472. DOI 10.1007/s12230-015-9455-7.

Rouppe van der Voort J., Lindeman W., Folkertsma R., Hutten R., Overmars H., van der Vossen E., Jacobsen E., Bakker J. A QTL for broadspectrum resistance to cyst nematode species (Globodera spp.) maps to a resistance gene cluster in potato. Theor. Appl. Genet. 1998;96: 654-661. DOI 10.1007/s001220050785.

Rouppe van der Voort J., van der Vossen E., Bakker E., Overmars H., van Zandvoort P., Hutten R., Klein Lankhorst R., Bakker J. Two additive QTLs conferring broadspectrum resistance in potato to Globodera pallida are localized on resistance gene clusters. Theor. Appl. Genet. 2000;101:1122-1130. DOI 10.1007/s001220051588.

Schultz L., Cogan N.O.I., McLean K., Dale M.F.B., Bryan G.J., Forster J.W., Slater A.T. Evaluation and implementation of a potential diagnostic molecular marker for $\mathrm{H} 1$-conferred potato cyst nematode resistance in potato (Solanum tuberosum L.). Plant Breed. 2012; 131:315-321. DOI 10.1111/j.1439-0523.2012.01949.x.

Skupinová S., Vejl P., Sedlák P., Domkáŕová J. Segregation of DNA markers of potato (Solanum tuberosum ssp. tuberosum L.) resistance against Ro1 pathotype Globodera rostochiensis in selected $\mathrm{F}_{1}$ progeny. Rostlinná Výroba. 2002;48(11):480-485. DOI 10.17221/ 4399-PSE.

State Register of Selection Achievements Authorized for Use for Production Purposes. Vol. 1. Plant Varieties (official publication). Moscow: Rosinformagrotech Publ., 2019. (in Russian)

Toxopeus H.J., Huijsman C.A. Breeding for resistance to potato root eelworm. I. Preliminary data concerning the inheritance and the nature of resistance. Euphytica. 1953;2(3):180-186. DOI 10.1007/ BF00053725.

\section{ORCID ID}

I.V. Totsky orcid.org/0000-0001-5565-9097

E.K. Khlestkina orcid.org/0000-0002-8470-8254

A.V. Kochetov orcid.org/0000-0003-3151-5181

Acknowledgements. The study of the bioresource collection of potatoes for the presence of genes for resistance to Globodera rostochiensis was carried out as part of the Russian Science Foundation 16-16-04073P grant. The study of the bioresource collection of potatoes for the presence of genes for resistance to Synchytrium endobioticum was performed as part of the CPSR "Development of Potato Breeding and Seed Production" (Comprehensive Plan of Scientific Research, CPSR). Reproduction and maintenance of the collection of varieties and hybrids of potatoes was carried out as part of the budget project of the Institute of Cytology and Genetics SB RAS (project No. 0259-2019-0011).

We are grateful to the staff of the laboratory of plant immunity to diseases of All-Russian Institute of Plant Protection (FSBSI VIZR) Afanasenko Olga Silvestrovna and Khiutti Aleksandr Valerievich for determining the resistance of potato hybrids to PCN and to the head of the All-Russian station for testing potatoes for resistance to wart and nematode of Russian Potato Research Center Manankov Vladimir Vyacheslavovich.

Conflict of interest. The authors declare no conflict of interest.

Received November 27, 2020. Revised June 25, 2021. Accepted June 25, 2021. 